\title{
Major challenges ahead for Hungarian healthcare
}

The health sector in Hungary is facing its most serious crisis since the fall of the communist regime. Péter Gaál and colleagues discuss the challenges and how to respond to them

\author{
Péter Gaál associate professor ${ }^{1}$, Szabolcs Szigeti national professional officer on health policy and \\ health systems ${ }^{2}$, Dimitra Panteli researcher ${ }^{3}$, Matthew Gaskins researcher ${ }^{3}$, Ewout van Ginneken \\ senior researcher ${ }^{34}$
}

\begin{abstract}
${ }^{1}$ Semmelweis University, Health Services Management Training Centre, Budapest, Hungary; ${ }^{2}$ WHO Country Office Hungary, Budapest, Hungary; ${ }^{3}$ Berlin University of Technology, Department of Health Care Management, Berlin, Germany ; ${ }^{4}$ European Observatory on Health Systems and Policies, Berlin
\end{abstract}

\begin{abstract}
Our recent review of the Hungarian health system laid bare some of the major challenges it faces today. ${ }^{1}$ Although Hungary's problems are not unique, their size sets this nation of 10 million people apart. The country has some of the worst health indicators in Europe, and public funding of its health system, which has long been inadequate, is currently in decline. Out of pocket expenses are high and the system encourages informal payments. At the same time, the health workforce in Hungary is shrinking because of migration of skilled professionals, threatening the sustainability of the system. In this article we look at some of the successes and failures of recent health reforms and suggest a way forward.
\end{abstract}

\section{System faced with poor population health}

Since the collapse of the communist regime in 1989, Hungary has built a mixed health system, based on a single payer, the National Health Insurance Fund Administration (NHIFA), which is funded from payroll contributions and general taxes (box 1). The NHIFA contracts with local government owned providers and pays for the services on the basis of diagnostic related groups in acute inpatient care, weighted patient days in chronic inpatient care, and a fee for service point system in outpatient specialist care; primary care doctors get a fixed amount per enrolled resident, adjusted by age. Although general practitioners are meant to act as gatekeepers, payment incentives weaken this role and use of hospital services is high. Between 1995 and 2008, non-diagnostic referrals to outpatient specialist care almost tripled, and the number of hospital referrals per patient increased by $66.5 \% .^{2}$ Patients can consult a wide range of specialists without referral, including dermatologists, otolaryngologists, obstetricians, gynaecologists, ophthalmologists, oncologists, urologists, and psychiatrists. Hungary had 12 outpatient contacts per person in 2009, almost twice the European Union (EU) average. ${ }^{3}$
The health sector has been struggling with an unfavourable fiscal context and an ill and ageing population. Life expectancy at birth in Hungary has consistently remained among the lowest in Europe, trailing the European Union average by 5.1 years in 2009 (fig $1 \Downarrow$ ). The improvements seen since 1993 have done little more than ensure that the gap between Hungary and the rest of the EU has not widened.

The main causes of death in Hungary are diseases of the circulatory system, cancer, and conditions of the digestive system - a pattern that has remained essentially unchanged since 2000 (table $1 \Downarrow$ ). ${ }^{4}$ The main culprits are the traditionally unhealthy Hungarian diet, alcohol consumption, and smoking. For example, $31.4 \%$ of the population aged over 15 years were regular daily smokers in 2009 , the highest among the EU countries for which recent data are available. Unsurprisingly, in 2009, the death rate from causes related to alcohol and smoking was almost twice the average in the rest of Europe. ${ }^{3}$

The picture is more positive for infant and maternal mortality, some avoidable causes of death, and especially mortality from communicable diseases (table $2 \Downarrow$ ). This is because Hungary has managed to maintain and improve the well functioning communicable disease control system, the compulsory child vaccination programme, and the primary care network of mother and child health nurses, which all date back to the communist era.

\section{Effects of harsh cost containment measures}

The macroeconomic climate in Hungary has been shaped by the efforts of successive governments to bring recurring budget deficits under control. In the health sector, periods of cost containment have alternated with periods of increased public spending, complicating long term planning and investment decisions. It has also led to a substantial overall drop in public expenditure on health, which fell from a high of $7.1 \%$ of gross 


\section{Box 1: Overview of healthcare financing in Hungary}

During the communist era, Hungary had a highly centralised, tax funded health system based on the Soviet Semashko model, characterised by the exclusive dominance of the state, a strong focus on specialist and hospital care, a low prestige primary care service, low paid doctors. and widespread informal payment.

In 1989, a Bismarckian social health insurance system was introduced with compulsory, non-risk related payroll contributions pooled in the Health Insurance Fund, administered by the NHIFA. Since the mid-1990s, the government has gradually regained more control over the NHIFA. The autonomous body that supervised the NHIFA was abolished in 1998 and the contribution rate was lowered substantially. In 2009, general tax revenue became the dominant source of funding. In effect, the system has become a hybrid model, combining elements of social insurance with an NHS-type system. Local governments are responsible for health service delivery and own most health facilities. GPs are mostly private entrepreneurs and pharmacies are $100 \%$ privately owned. In 2011 , the new government decided to take over the local government owned hospitals and polyclinics from next year.

\section{Box 2: Hungary's health service delivery system}

- Public health services are delivered through the National Public Health and Medical Officer Service

- Primary care comprises general practice services, dental care, out of hours care, and maternal and child care (through a nationwide network of health nurses) and falls within the remit of the municipalities

- Secondary and tertiary care is shared among the municipalities, counties, the central government, and, to a lesser extent, private providers. Hungary has followed the general European trend of reducing the number of acute hospital beds. Day care has been fostered through regulations and special financing schemes, especially over the past 15 years

- Long term care is provided by the health and the social sectors

- Local governments are responsible for providing social care, which takes the form of cash and in-kind benefits provided mostly to people who are poor or disabled

- Mental healthcare is integrated into the main health and social care systems

- Most dental services are available free of charge at the point of access, but the use of private dental care is widespread

domestic product in 1994 to $5.2 \%$ in 2009—whereas the proportion grew in many other European nations (fig $2 \Downarrow$ ). ${ }^{5}$ This decline may threaten the sustainability of universal coverage.

Any savings from increased efficiency in the health system have been consistently diverted out of the health sector. The budget for the National Health Promotion Programme in 2007, for instance, was only a third of what it was in $2003{ }^{6}$

The most recent austerity package, which aimed to help Hungary meet the Maastricht criteria for joining the European monetary union, was enacted well before the global economic crisis hit in the autumn of 2008. An increase in the unemployment rate from $7.1 \%$ in early 2007 to $11.6 \%$ in early 2011 has led to a decrease in contributions and further cuts in public spending. ${ }^{7}$ The macroeconomic climate remains unfavourable, and the government must continue to observe tough deficit targets set by the EU. Substantial increases in public spending on health should therefore not be expected in the near future, despite government declarations to the contrary. ${ }^{8}$

To offset falls in public expenditure, government has aimed to shift part of the financial burden to patients by restricting the benefit package (box 3). As a result, household out of pocket spending increased from $16 \%$ of total health expenditure in 1995 to $25.2 \%$ in 2008. Drugs account for the largest amount of out of pocket expenses (table $3 \Downarrow$ ). There are standard tariffs, and the NHIFA reimburses either a percentage (25-100\%) or a fixed amount. For fully reimbursed drugs patients have to pay a flat fee of 300 forint (about $£ 0.90 ; € 1.05 ; \$ 1.40$ ) per package.

A sizeable share of out of pocket expenses also goes on informal payments. These payments, which are made to doctors and, to a lesser extent, other health workers for services that should be free of charge, are a legacy of the communist era and remain despite attempts to formalise them. ${ }^{9}$ On average doctors earn $66-250 \%$ of their net official salary informally, ${ }^{10}$ with obstetricians and surgeons receiving the most; a typical payment for a delivery in Budapest is around 100000 forint. Gratitude is said to be the main motivating factor, but evidence exists that patients are subject to a wide range of external and internal pressures to pay. ${ }^{11}$

\section{Health workforce crisis}

The harsh cost containment programmes implemented since the mid-1990s have had direct repercussions on the health workforce, which mostly comprises salaried public employees. Wage freezes and cuts have made jobs in healthcare less attractive. Salaries have been falling as a share of the average wage since 2005, and since the financial crisis struck in 2008 they have also decreased in absolute terms. ${ }^{12}$

Wages are a major driver for professional mobility in the EU, and Hungary is no exception. ${ }^{13}$ In 2009 , general practitioners' salaries were 1.4 times the average Hungarian wage and specialists 1.6 times the average, considerably lower ratios than those seen in some other European countries. Unsurprisingly, the number of doctors seeking higher pay abroad (mainly in the UK, Germany, Italy, and Austria) is rising, making Hungary a net donor country in terms of physician migration. Moreover, the outflow of health professionals seems to be increasing substantially while the inflow is diminishing. The number of foreign nurses who registered to practise in Hungary in 2008, for example, was $45 \%$ below that seen in $2005 .{ }^{14}$

Low wages, migration, reductions in capacity, and the ageing of health professionals $-8.2 \%$ of practising doctors in Hungary were aged over 61 in $2007^{15}$ - have taken their toll on the health workforce, which fell from 129000 in 2003 to 107106 in $2010 .{ }^{16}$ Figure $3 \Downarrow$ shows that ratios of doctors and nurses to population in Hungary are lower than the average for the EU.

It is not the current numbers of staff but the trend that is alarming because it could worsen problems with workforce distribution, especially in rural and remote areas. Large disparities already exist by region, level, and type of care as well as profession and specialty. Shortages exist in primary care, anaesthetics and intensive care, radiology, emergency medicine paediatrics, and neurology.$^{17}$ In contrast, the per capita numbers of dentists increased by $56 \%$ between 2000 and $2008 .^{3}$ This can be explained by the better economic opportunities in the private market and, perhaps ironically, by increasing numbers of foreign patients coming to Hungary for affordable dental treatment. ${ }^{18}$ 


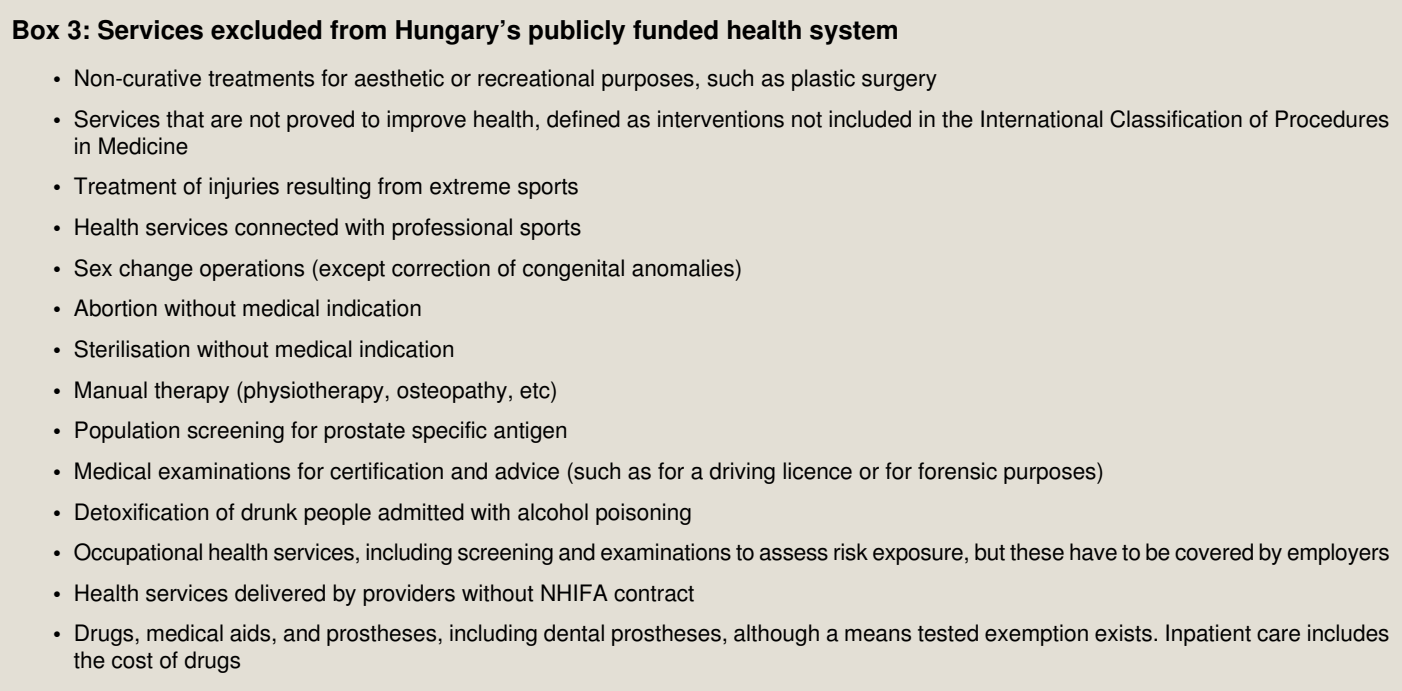

\section{Responding to the challenges}

The challenges facing the Hungarian health system are great. Since more money is unlikely to be forthcoming, improvements must be achieved through efficiency gains rather than increased public spending. Successive governments have failed to formulate a consistent legal and financial framework that would provide a stable and predictable flow of resources for the health system. However, a hypothecated tax on unhealthy foods introduced in September 2011, although likely to provide only small amounts of revenue, is a promising initiative.

The most important inefficiency is the lack of coordination between healthcare providers within and across levels of care, as well as between the health and the social sectors. Although reforms have mainly looked at public sector solutions to these problems, initiatives to privatise hospitals and to introduce a competitive health insurance model have regularly entered the debate. Parliament approved a plan to partly privatise the management of the NHIFA and to entrust the coordination of care to for profit companies in early 2008 , but it was repealed only months later after the public voted against user charges in a national referendum. The current government has reverted to a public sector approach and recently decided to nationalise the 12 hospitals of the municipality of Budapest. This measure has been extended to all other local government owned hospitals and polyclinics, which represents another major step towards an NHS-type system.

Incentives for providers to work more efficiently are sorely needed, as are measures to eliminate corruption. A care coordination pilot from 1999 tackled these problems as well as the lack of vertical integration between providers. It showed promising results but was dismantled in 2008 (box 4). ${ }^{19}$ The government would be well advised to build on the experiences of such innovative models using combinations of better coordination and bundled payments.

Action is also needed to deal with the crisis in the health workforce. Although wage increases seem unlikely, other strategies are available. When asked in a recent survey about their reasons for leaving Hungary to work abroad, emigrant doctors cited the working environment (such as terms of employment, lower working hours, less administrative burden), the future perspective of Hungarian healthcare, career opportunities, and social prestige almost as often as higher pay. ${ }^{17}$ The government should consult the workforce to assess which non-monetary incentives (study leave, vacation, flexible working hours, access to training and education, occupational health counselling, recreational facilities, etc) could make the health professions more attractive.

Lastly, a more comprehensive approach to measuring system performance would be beneficial. ${ }^{20}$ It could improve governance by encouraging (or even requiring) the use of evidence in policy decisions and by making the system more transparent and accountable. Until now, such efforts have focused mostly on financial performance and provider activity. Although the NHIFA has been collecting detailed patient level data on use of healthcare services and drugs since 1993, this rich dataset has yet to be used extensively for monitoring and evaluation. Not until such obvious deficiencies are overcome will there be sustainable improvements in the performance of the Hungarian health system.

Contributors and sources: PG, SS, DP, and MG have recently completed the 2011 Hungary health systems review (HiT), which served as the basis of this paper. EVG, DP, and MG have extensive experience with health systems in Europe and especially in the new EU member states through their involvement with the European Observatory on Health Systems and Policies. PG is an expert on health policy and the Hungarian health system; he was the lead author of the 1999 and 2004 HiT profiles. SS has worked as national policy officer in the WHO Country Office in Hungary on health system and policies. EVG devised the article and wrote the first draft, which was revised by PG and SS. EVG, DP, PG, SS, and MG contributed to subsequent drafts. The last draft was revised by EVG and MG. A revised draft was prepared by EVG and PG. All have read and agreed with the final version. EVG is the guarantor.

Competing interests: All authors have completed the ICJME unified disclosure form at www.icmje.org/coi_disclosure.pdf (available on request from the corresponding author) and declare no support from any organisation for the submitted work and no financial relationships with any organisation that might have an interest in the submitted work in the previous three years. $P G$ is an unpaid adviser to the state secretary for health in the Ministry of National Resources and is an unpaid member of his cabinet.

Provenance and peer review: Commissioned; externally peer reviewed.

1 Gaál P, Szigeti S, Csere M, Panteli D, Gaskins M. Hungary: health system review. Health Systems in Transition 2011;13:1-266.

2 Hungarian Central Statistical Office. Yearbook of health statistics 2008. Hungarian Central Statistical Office, 2009.

3 WHO Regional Office for Europe. European Health for All database (HFA-DB). www.euro. who.int/hfadb (accessed May 2011).

4 Ádány R. A magyar lakosság egészségi állapota, különös tekintettel az ezredforduló utáni időszakra [The health status of the Hungarian population, with special reference to period after the turn of the millennium]. Népegészségügy 2008;86:5-20. 


\section{Box 4: Innovative Hungarian care coordination system}

A pilot care coordination system was introduced in 1999 to tackle the shortcomings of incentives in the existing payment systems. The concept was that healthcare providers (either a hospital, a polyclinic, or a group of GPs) would take responsibility for the entire spectrum of care of a population group (initially up to 200000 people). Care coordinator organisations could collaborate with other providers to optimise the treatment of their patients. They were assigned a virtual budget based on the number of people in the catchment area multiplied by a risk adjusted capitation fee. If the total cost incurred during the year was lower than the virtual budget, the difference was paid to the care coordinators and could be used for remuneration and investment. The project was criticised, mainly for lack of transparency and inequitable distribution, and was abolished in December 2008 despite documented successes during its first few years of operation.

This paper was prepared in conjunction with the European Observatory on Health Systems and Policies (www.healthobservatory.eu).

5 Organisation for Economic Cooperation and Development. OECD health data: health expenditure and financing. 2011. www.oecd.org/health/healthdata.

6 Ministry of Health. Tájékoztató az Egészség évtizedének népegészségügyi programja 2007. évi elörehaladásáról [Report on the progress of the implementation of the decade of national public health programme in 2007]. 2008. www.eum.hu/archivum/eloterjesztesek/ egeszseg-evtizedenek-090921

7 Eurostat. EU labour force survey. $2011 \mathrm{http}: / /$ epp.eurostat.ec.europa.eu/portal/page/portal/ employment unemployment Ifs/introduction.

8 Government of the Hungarian Republic. A Nemzeti Együttmüködés programja [The programme of the National Cooperation]. 2010. www.parlament.hu/irom39/00047/00047. pdf.

9 Gaál P, Jakab M, Shishkin S. Strategies to address informal payments for health care. In: Kutzin J, Cashin Ch, Jakab M, eds. Implementing health financing reforms: lessons from countries in transition. WHO, European Observatory on Health Systems and Policies, 2010:327-61.

10 Gaál P, Evetovits T, McKee M. Informal payments for health care: evidence from Hungary. Health Policy 2006;77:86-102.

11 Gaál P. Informal payments for health care in Hungary. [PhD thesis]. London School of Hygiene and Tropical Medicine, 2004

12 Hungarian Central Statistical Office. Household statistics. 2011. http://portal.ksh.hu/pls/ ksh/docs/eng/xstadat/xstadat annual/i zhc004.html.

13 Hungarian Central Statistical Office. STADAT tables, employment. 2011. http://portal.ksh $\mathrm{hu} / \mathrm{pls} / \mathrm{ksh} /$ docs/hun/xstadat/xstadat_eves/__qlf002.html.

14 Wismar M, Maier CB, Glinos IA, Dussault G, Figueras J, eds. Health professional mobility and health systems: evidence from 17 European countries. WHO, European Observatory on Health Systems and Policies [forthcoming]
15 Ministry of Health. Tájékoztató az egészségügyben dolgozók létszámhelyzetének alakulásáról [Report on the trends of the numbers of health professionals]. Ministry of Health, 2009.

16 National Institute for Strategic Health Research. Összefoglaló tájékoztató az egészségügyben dolgozók létszám- és bérhelyzetéről 2010 IV. negyedév [Summary report on the number and wages of health professionals in the final quarter of 2010]. 2011. www.eski.hu/new3/adatok/berstatisztika/OSAP1626-eves-CD/index.htm.

17 Eke E, Girasek E, Szócska M. From melting pot to change lab central Europe: health workforce migration in Hungary. In: Wismar M, Maier C, Glinos IA, Dussault G, Figueras $\mathrm{J}$, eds. Health professional mobility and health systems: evidence from 17 European countries. WHO, European Observatory on Health Systems and Policies [forthcoming].

18 Kámán A. Fogászati turizmus mint az egészségügyi turizmus húzóága [Dental tourism as the driving force of health tourism]. Association of Leading Hungarian Dental Clinics conference presentation, Utazás, 4-7 March 2010.

19 Gaál P. Health care systems in transition: Hungary. WHO Regional Office for Europe, 2004.

20 Gaál P, Szigeti S, Gaskins M. Responsibility and accountability in the Hungarian health system. In: Rosen B, Israeli A, Shortell S, eds. Accountability and responsibility in health care-an emerging global issue. World Scientific [forthcoming].

Accepted: 01 November 2011

Cite this as: BMJ 2011;343:d7657

(c) BMJ Publishing Group Ltd 2011 


\section{Tables}

Table 1| Main causes of death (standardised death rate/100 000) in Hungary and the EU3

\begin{tabular}{lccc} 
& \multicolumn{2}{c}{ Hungary } & \\
\cline { 2 - 3 } & 2000 & 2009 & EU (2009) \\
Diseases of circulatory system & 521.0 & 421.2 & 232.8 \\
\hline Ischaemic heart disease & 226.9 & 214.8 & 86.4 \\
\hline Cerebrovascular disease & 141.7 & 90.8 & 55.5 \\
\hline Cancer & 268.2 & 243.2 & 171.9 \\
\hline Trachea/bronchus/lung & 65.0 & 65.9 & 37.3 \\
\hline Breast (female) & 32.5 & 28.1 & 23.5 \\
\hline Cervical & 7.3 & 5.9 & 3.3 \\
\hline Diseases of digestive system & 87.0 & 65.6 & 31.5 \\
\hline Chronic liver disease and cirrhosis & 60.1 & 41.3 & 13.7 \\
\hline Respiratory diseases & 40.3 & 44.3 & 44.1 \\
\hline Diseases of nervous system and mental disorders & 22.2 & 29.6 & 29.5 \\
\hline Diabetes & 17.3 & 17.9 & 12.4 \\
\hline Injuries and poisoning & 82.2 & 59.0 & 37.8 \\
\hline Suicide and self inflicted injury & 29.2 & 21.8 & 10.4 \\
\hline Road traffic injuries & 12.0 & 8.5 & 7.0 \\
\hline
\end{tabular}


Table 2| Infant and maternal mortality, mortality from and incidence of selected communicable diseases in Hungary and EU3

\begin{tabular}{|c|c|c|c|c|}
\hline \multirow[b]{2}{*}{ Death rate/incidence } & \multicolumn{3}{|c|}{ Hungary } & \multirow[b]{2}{*}{ EU $(2009$} \\
\hline & 1990 & 2000 & 2009 & \\
\hline Infant deaths/1000 live births & 14.8 & 9.2 & 5.1 & 4.3 \\
\hline Probability of dying before age 5 years (/1000 births) & 16.8 & 10.8 & 6.0 & 5.1 \\
\hline Maternal deaths/100 000 live births & 20.7 & 10.3 & 18.7 & 6.3 \\
\hline Infectious and parasitic diseases (deaths/100 000 population) & 8.5 & 5.6 & 3.8 & 8.8 \\
\hline \multicolumn{5}{|l|}{ Infectious diseases (cases/100 000 population): } \\
\hline Pertussis & 0.1 & 0.01 & 0.3 & 3.8 \\
\hline Measles & 0.3 & 0.01 & 0.01 & 1.3 \\
\hline Mumps & 205.7 & 2.2 & 0.1 & 7.1 \\
\hline AIDS & 0.2 & 0.3 & 0.2 & 1.0 \\
\hline
\end{tabular}


Table 3| Out of pocket health expenditures per person in Hungary by year12

\begin{tabular}{lcccccc} 
& 2000 & 2005 & 2006 & 2007 & 2008 & 2009 \\
Total (Forint) & 13719 & 26502 & 26577 & 30772 & 33300 & 34969 \\
\hline \% of total: & & & & & & \\
\hline Medicines & 60.7 & 65.6 & 65.0 & 68.6 & 71.5 & 70.9 \\
\hline Medical aids and prostheses & 9.5 & 10.0 & 11.5 & 9.6 & 9.6 & 9.3 \\
\hline Outpatient care & 29.2 & 9.5 & 8.9 & 8.7 & 7.4 & 6.7 \\
\cline { 1 - 5 } Dental care & & 9.5 & 9.9 & 8.6 & 7.0 & 7.4 \\
\cline { 1 - 5 } Inpatient care & & 4.4 & 4.1 & 3.8 & 3.6 & 4.6 \\
\hline Informal payments & 6.8 & 9.0 & 9.2 & NA & NA & NA \\
\hline & & & & & &
\end{tabular}

1 Forint $=£ 0.002(€ 0.003 ; \$ 0.004)$ at current exchange rates. 


\section{Figures}

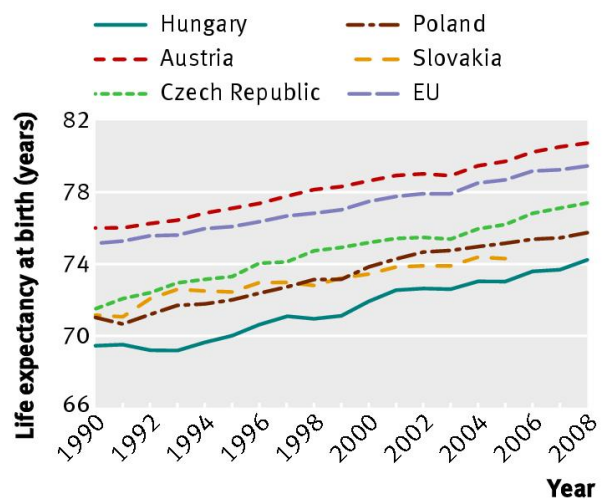

Fig 1 Life expectancy at birth (in years) in selected countries, 1990 to 2008 (or latest available year) ${ }^{3}$

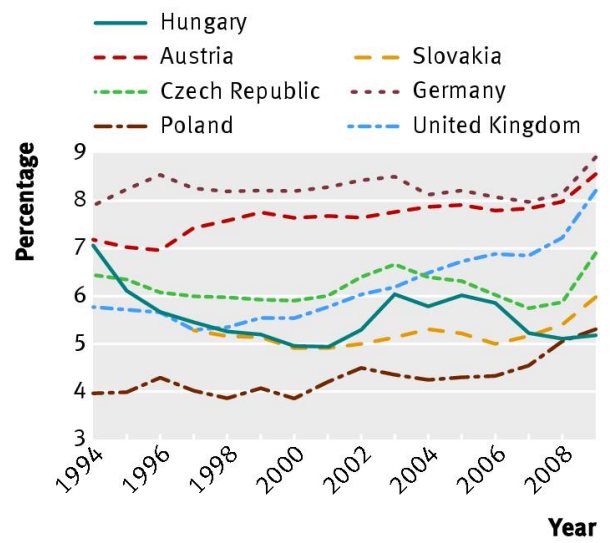

Fig 2 Public expenditure on health as percentage of gross domestic product in selected countries, 1994 to $2009^{5}$

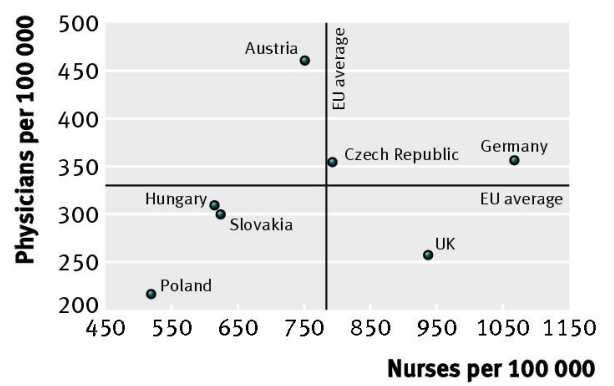

Fig 3 Number of nurses versus number of doctors per 100000 population in Hungary and selected countries and averages in 2008 (or latest available year) ${ }^{3}$ 